\title{
The Role of PAR1 Autoantibodies in Patients with Primary Epithelial Ovarian Cancer
}

\author{
KATRIN KREIENBRING ${ }^{1}$, ANNIKA FRANZ ${ }^{1}$, ROLF RICHTER ${ }^{1}$, DUSKA DRAGUN $^{2}$, HARALD HEIDECKE $^{3}$, \\ DOMINIK MÜLLER ${ }^{4}$, MONIKA MENTZE $^{1}$, RALF DECHEND $^{4}$, JALID SEHOULI $^{1}$ and ELENA IOANA BRAICU ${ }^{1}$ \\ Departments of ${ }^{1}$ Gynecology, and ${ }^{2}$ Nephrology and Critical Care Medicine, \\ Charitè University Berlin, Berlin, Germany, \\ ${ }^{3}$ CellTrend, Luckenwalde, Germany; \\ ${ }^{4}$ Experimental and Clinical Research Center, Berlin, Germany
}

\begin{abstract}
Aim: This study aimed to analyze the predictive, prognostic and diagnostic value of autoantibodies to coagulation factor II thrombin receptor (F2R; proteaseactivated receptor 1, PAR1) (PAR1-AB) in patients with primary epithelial ovarian cancer (EOC). Materials and Methods: A total of 197 patients with primary EOC and 200 healthy female blood donors were included in the study. Enzyme-linked immunosorbent assay was applied to determine PARI-AB levels in blood sera taken preoperatively. Correlation of PARI-AB with clinicopathological outcome, progression-free (PFS) and overall $(O S)$ survival was analyzed and patients were compared with controls. Results: PAR1-AB was significantly negatively correlated with histological grading $(p=0.008)$ and was significantly lower in the patient group compared to healthy controls $(p<0.001)$. There was no significant correlation of PAR1-AB level with PFS or OS. Conclusion: This study showed $P A R I-A B$ to significantly decrease in patients with primary EOC and with histological high-grade carcinoma. The relevance of $P A R I-A B$ in early detection of ovarian cancer and follow-up for EOC should be further investigated.
\end{abstract}

With a 5-year-survival of $92 \%$ in patients with early Fédération Internationale de Gynécologie et d'Obstétrique (FIGO) stages to $6 \%$ in those with advanced-stage disease, epithelial ovarian cancer (EOC) is the most lethal disease among gynaecological cancers. However, only about $15 \%$ of all cases are diagnosed in FIGO stage I (1). The rapid lymphatic and peritoneal dissemination combined with late and non-specific symptoms

Correspondence to: Katrin Kreienbring, Charité Virchow Klinikum, Frauenklinik, TOC-Labor, Augustenburger Platz 1, 13353 Berlin, Germany. Tel: +49 1775501655, e-mail: katrin.kreienbring@gmx.de

Key Words: Ovarian cancer, diagnostic, epithelial neoplasm, protease activated receptor 1, factor II thrombin receptor, clinicopathological outcome, metalloproteinases. makes the development of sufficient screening methods even more important. Currently, there are no early detection methods, such as transvaginal ultrasound or cancer antigen 125 (CA-125) level, which have been shown to be clinically useful. Standard-of-care for EOC is surgery followed by platinum taxane-based chemotherapy. Even though only $20 \%$ of EOCs are resistant to chemotherapy, more than $60 \%$ of patients will experience relapse (2). This is based on the advanced FIGO stage at diagnosis and molecular complexity of EOC that leads to development of chemotherapy-resistant clones. Additional approaches are targeted therapies which seem to improve progression-free survival (PFS), but unfortunately have no impact on overall survival (OS) (3). Therefore, the knowledge of EOC biology, for example signal transduction pathways, tumour-suppressor genes and proliferation factors, is essential. Simultaneously powerful predictive markers to identify specific targeted therapies for patients are needed. Random tumour markers and markers that have been found to be up-regulated in EOC are a focus of research.

Many proteases that are secreted or produced during tissue damage are able to activate PARs. Coagulation factor II thrombin receptor F2R [protease-activated receptor 1 (PAR1)] is a G-protein-coupled receptor (4) found to be overexpressed in various epithelial neoplasms, such as laryngeal (5), pancreatic (6), renal cell (7), prostatic (8), breast (9-11), colonic $(12,13)$, lung (14) and ovarian cancer (15). PAR1 is also known to be expressed in acute lymphoblastic leukaemia (16), as well as malignant melanoma, and correlates with its metastatic activity (17) and angiogenesis (18). Wojtukiewicz et al. were the first to identify this receptor on rat sarcoma and mice melanoma cells in 1995 (19).

Many proteases that are secreted or produced during tissue damage are able to activate PARs. The tumour microenvironment is replete of such proteases, while tumour cells themselves secrete PAR1 on their surface. Such proteolytic enzymes are metalloproteinases (MMP) such as MMP1, which is a collagenase and agonist of PAR1. The 
proteolytic properties of MMP1 can reduce adhesion between cells and facilitate cell motility. This is suggested to explain the association of PAR1 with increased metastasis (20).

The most frequent agonists of PAR 1 are thrombin and trypsin (21), as well as plasmin (22), factor Xa (23) and activated protein C (24). Recently our group showed that regulators of the plasminogen activator system, plasminogen activator inhibitor type 1 (PAI1) and PAI-mRNA binding protein type 1 (PAI-RBP1), are predictive markers of outcome in EOC (25). Many carcinomas are known to secrete thrombin, including EOC (26). Binding of thrombin to PAR1 (PAR1-thrombin) has been shown to release growth factors in EOC (27), which promote angiogenesis, prosurvival signalling and metastasis, lead to poor survival (28) and prevent apoptosis in patients with EOC (29). In a study by Karabulut et al., no predictive or prognostic value of PAR1 was found in a group of 44 patients with EOC but it was significantly up-regulated in the serum of the patient group compared with controls $(p=0.03)$ (30).

There is increasing evidence that autoantibodies against PAR1 (PAR1-AB) inhibit PAR1 and thereby reduce migration and invasion of cancer cells. Shi et al. showed that binding between PAR1-AB and PAR1 averts cleavage and activation of the receptor by MMP1 in HER2-negative breast cancer tissue and reduces velocity of the affected cells, as well as the number of invading cells (31). In another study, Shi et al. showed that blocking PAR-1 with PAR1-AB and a monoclonal antibody against the thrombin-binding region on human metastatic melanoma cells significantly inhibited migration (32). As those studies suggest PAR1-AB products to be potential anticancer drugs, the intention of this study was to analyse the level of PAR1-AB in patients with EOC and examine its clinical significance. We anticipated decreased PAR-1 AB level in patients compared with healthy controls and patients with advanced disease.

\section{Materials and Methods}

Patients. The serum samples of 197 patients with primary EOC, median age at diagnosis was 60 years (range $=28-92$ years), were taken before cytoreductive surgery. These were collected between 2000 and 2011 and the data of the patients was updated by the Tumor Bank of Ovarian Cancer (TOC) (http://www.tocnetwork.de/). TOC is a multicentre project that started in 2000 at the Department of Gynaecology at Campus Virchow Clinics Berlin, Germany. For more than 15 years, the clinics have specialised in multimodal therapy of ovarian cancer. The follow-up ended 2013 and was a mean of 44.8 months.

For comparison, serum samples from 200 healthy asymptomatic women with a median age of 57.5 years (range $=42-83$ years) were collected at the University Medical Center Göttingen, and processed using the same protocol.

The serum levels of PAR1-AB were assayed by CellTrend GmbH (http://www.celltrend.de/) using an enzyme-linked immunosorbent assay (ELISA).
PAR1-AB ELISA. PAR1-ABs were measured in serum samples using a sandwich ELISA kit (CellTrend GmbH, Luckenwalde, Brandenburg, Germany). The microtitre 96-well plates were coated with chemically synthesized human PAR 1 isoform 1 (SEQ ID NO:1, Figure 1) (CellTrend GmbH, Luckenwalde, Brandenburg, Germany). To maintain the conformational epitopes of the receptor, $1 \mathrm{mM}$ calcium chloride was added to every buffer. Duplicate samples of a 1:100 serum dilution were incubated at $4^{\circ} \mathrm{C}$ for 2 hours. After washing steps, plates were incubated for 60 minutes with a 1:20.000 dilution of horseradish-peroxidase-labeled goat anti-human IgG (Jackson ImmunoResearch Laboratories, Inc., West Grove, PA, USA) used for detection. In order to obtain a standard curve plates were incubated with test sera from a PAR1-AB-positive index patient. The ELISA was validated according to the FDA's "Guidance for Industry: Bioanalytical Method Validation" (33). To set a standard for the concentration of PAR1-AB, a standard curve was generated. A serum sample of a patient with systemic sclerosis was diluted 1:100, 1:200,1:400, 1:800 and 1:1,600 for standards of $40,20,10,5$ and 2.5 Units $/ \mathrm{ml}$, respectively. The optical density was then determined. Each standard was determined in duplicates.

Statistical methods. For statistical evaluation, IBM SPSS Statistics ver. 22 (IBM Corp., Armonk, NY, USA) was used. Mann-Whitney U-test and Kruskal-Wallis test were applied for the association of PAR1-AB level with clinical and pathological factors, PFS and OS, patients and healthy controls. The $\alpha$-level was assumed at less than 0.05 and all tests were two-sided. The survival distribution was assessed with Kaplan-Meier estimator and the equality of survival distribution for the different serum levels was tested with log-rank test (Mantel-Cox). Any clinically or histologically confirmed cancer recurrence was defined as an event for the calculation of PFS. The duration of OS was defined as the interval between the date of diagnosis and the death of the patient.

Ethics statement. The Ethical Committee of Charité Medical University, Berlin (no. 207/2003) and University Medical Center Göttingen (No. EK 22/2/04) grated ethical approval for these investigations. The patients gave their written informed consent to participation before enrolment and sample collection.

\section{Results}

In this study, serum samples of 197 patients with primary EOC were analysed for PAR1-AB. Table I shows patient characteristics and distribution of their age, FIGO stage, histology, clinical factors and response to platinum-based chemotherapy. Nearly $92 \%$ of patients already had an advanced tumour disease (FIGO III/IV) at diagnosis. Two patients $(1.02 \%)$ were treated with neoadjuvant chemotherapy. After primary surgery, 35 patients (17.8\%) needed completion surgery and two patients (1.02\%) interval debulking after chemotherapy. Chemotherapy was administered to 170 patients $(86.3 \%)$ over six cycles on average (range=1-16). Most of the patients received paclitaxel and carboplatin $(\mathrm{N}=154 ; 78.2 \%), 11(5.6 \%)$ of them were treated with other platinum-containing combinations and five patients $(2.5 \%)$ received immunotherapy. Platinum sensitivity was defined according to Gyneacologic Cancer InterGroup criteria (34) as 


\section{MGPRRLLLVA ACFSLCGPLL SARTRARRPE SKATNATLDP RSFLLRNPND \\ 51 KYEPFWEDEE KNESGLTEYR LVSINKSSPL QKQLPAFISE DASGYLTSSW \\ 101 LTLFVPSVYT GVFVVSLPLN IMAIVVFILK MKVKKPAVVY MLHLATADVL \\ 151 FVSVLPFKIS YYFSGSDWQF GSELCRFVTA AFYCNMYASI LLMTVISIDR \\ 201 FLAVVYPMQS LSWRTLGRAS FTCLAIWALA IAGVVPLLLK EQTIQVPGLN \\ 251 ITTCHDVLNE TLLEGYYAYY FSAFSAVFFF VPLIISTVCY VSIIRCLSSS \\ 301 AVANRSKKSR ALFLSAAVFC IFIICFGPTN VLLIVHYSFL SHTSTTEAAY \\ 351 FAYLLCVCVS SISCCIDPLI YYYASSECQR YVYSILCCKE SSDPSSYNSS \\ 401 GQLMASKMDT CSSNLNNSIY KKLLT}

Figure 1. Amino acid sequence of the human protease-activated receptor-1 (PAR1) (isoform 1) [SEQ ID NO:1].

no relapse within 6 months of platinum-based chemotherapy. After surgery eight patients $(4.1 \%)$ died from complications and 128 patients $(65 \%)$ had died by the end of the follow-up.

The mean and median serum levels of PAR $1-A B$ in the patient and control groups are presented in Table II. Serum PAR1-AB level was significantly negatively correlated $(p<0.001)$ with the presence of primary EOC (Figure 2$)$.

The correlation of serum PAR1-AB with clinicopathological factors is shown in Table III. PAR1-AB was significantly inversely correlated with histological grading $(p<0.007)$ but with none of the other listed factors. The median PAR1-AB of the low-grade group was $2.2 \mathrm{U} / \mathrm{ml}$ compared with $1.0 \mathrm{U} / \mathrm{ml}$ for the high-grade group (Figure 3 ).

The mean PFS of the whole patient group was 20.7 months (range $=0-114$ months), with a median of 14 months. The OS of the patient group was a mean of 34.9 months (range $=0.5$ 114 months with a median of 40 months. The patients were classified into three groups using the upper and lower quartiles of PAR1-AB distribution; PFS and OS were analysed according to these PAR1-AB groups (Table IV). Log-rank tests showed no significant relation of OS $(p=0.110)$ or PFS $(p=0.148)$ with PAR1-AB level (Figures 4 and 5).

\section{Discussion}

This investigation found the serum level of PAR1-AB to be significantly lower in patients with EOC versus healthy controls. Furthermore, PAR1-AB was significantly inversely correlated with histological grading. The prognosis of patients with EOC seems not to be predictable by PAR1-AB level.

It is suggested that serum antibodies are more reliable tumour markers than antigens because of their less inconsistent and more distinct serum levels, especially in early stages of carcinoma (35). In this study, the serum
Table I. Patient clinical and pathological characteristics ( $n=197)$.

\begin{tabular}{|c|c|}
\hline Parameter & Value \\
\hline \multicolumn{2}{|c|}{ Age at diagnosis, years } \\
\hline Median (range) & $60(28-92)$ \\
\hline \multicolumn{2}{|c|}{ Follow up period, months } \\
\hline Mean (range) & $44.8(3-114)$ \\
\hline \multicolumn{2}{|l|}{ Histology, n (\%) } \\
\hline Serous & $183(92.9)$ \\
\hline Endometrioid & $1(0.5)$ \\
\hline Clear cell tumour & $1(0.5)$ \\
\hline Mixed & $4(2.0)$ \\
\hline Other & $8(4.1)$ \\
\hline \multicolumn{2}{|l|}{ FIGO, n $(\%)$} \\
\hline I & $5(2.5)$ \\
\hline II & $11(5.6)$ \\
\hline III & $135(68.5)$ \\
\hline IV & $46(23.4)$ \\
\hline \multicolumn{2}{|c|}{ Histological grading, n (\%) } \\
\hline I & $8(4.1)$ \\
\hline II & $49(24.9)$ \\
\hline III & $140(71.0)$ \\
\hline \multicolumn{2}{|c|}{ Volume of ascites, $\mathrm{n}(\%)$} \\
\hline None & $47(23.9)$ \\
\hline$<500 \mathrm{ml}$ & $77(39.1)$ \\
\hline$>500 \mathrm{ml}$ & $73(37.0)$ \\
\hline \multicolumn{2}{|c|}{ Peritoneal carcinomatosis, $\mathrm{n}(\%)$} \\
\hline Present & $174(88.3)$ \\
\hline Absent & $23(11.7)$ \\
\hline \multicolumn{2}{|c|}{ Residual tumour mass, n (\%) } \\
\hline None & $105(53.3)$ \\
\hline$<0.5 \mathrm{~cm}$ & $34(17.3)$ \\
\hline$<1 \mathrm{~cm}$ & $30(15.2)$ \\
\hline $1-2 \mathrm{~cm}$ & $6(3.0)$ \\
\hline$>2 \mathrm{~cm}$ & $22(11.2)$ \\
\hline \multicolumn{2}{|c|}{ Response to platinum-based chemotherapy, n (\%) } \\
\hline Sensitive & $116(58.9)$ \\
\hline Resistant & $55(27.9)$ \\
\hline No such therapy & $26(13.2)$ \\
\hline
\end{tabular}




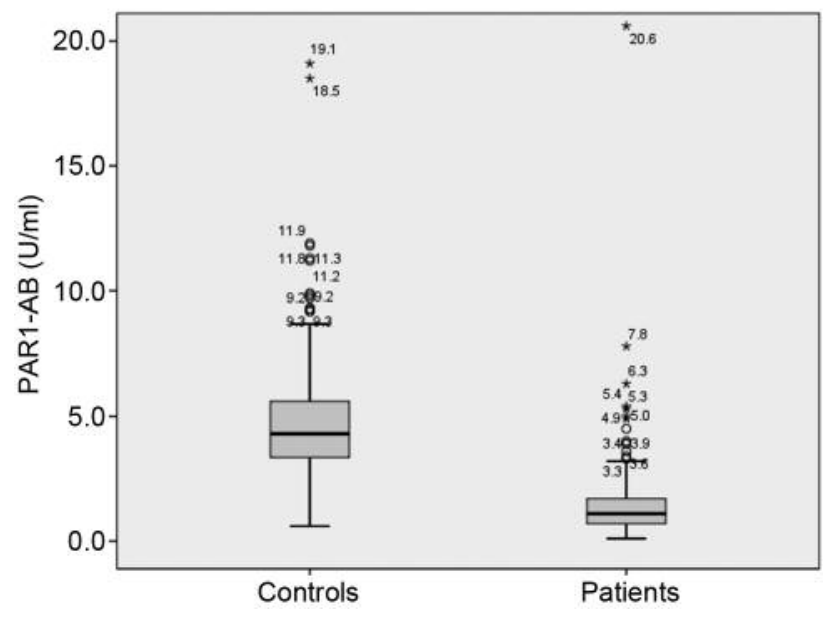

Figure 2. Serum protease-activated receptor-1 antibody (PAR1-AB) level in patients with epithelial ovarian cancer and controls. The level in patients was significantly lower $(p<0.001)$. $\square$ Interquartile range (25th75th percentile); - median; $\perp-\top^{-m i n-m a x ~ e x c e p t ~ o u t l i e r s ; ~} \bigcirc$ outliers $(>1.5$ times interquartile ranges); *extreme outliers (>3 times interquartile ranges).

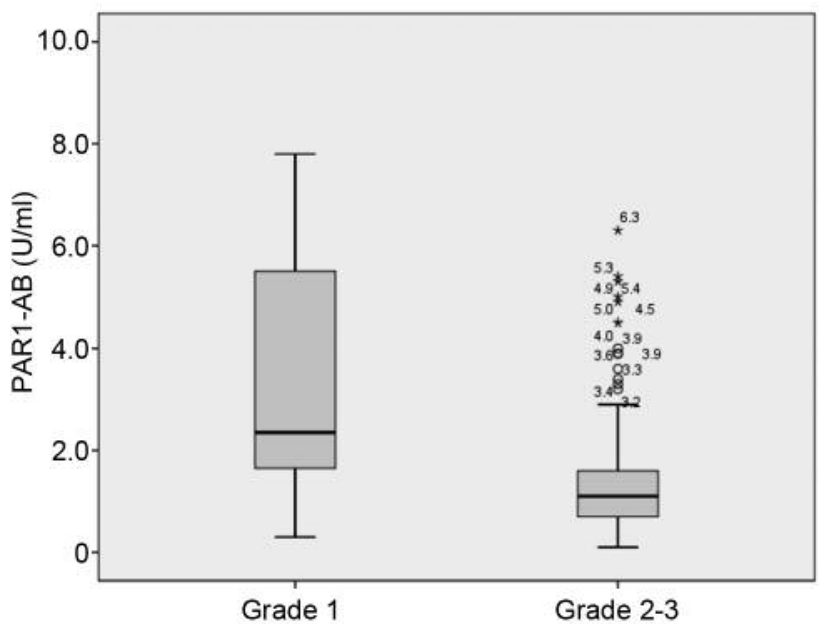

Figure 3. Serum protease-activated receptor-1 antibody (PAR1-AB) level in patients with epithelial ovarian cancer according to histological grading. The level of PAR1-AB was significantly lower in patients with grade 2 or 3 disease ( $p=0.007)$. $\square$ Interquartile range (25th-75th percentile); - median; $\perp$ - $\mathrm{\top}$ min-max except outliers; $\bigcirc$ outliers (>1.5 times interquartile ranges); *extreme outliers (>3 times interquartile ranges).

Table II. Mean and median serum protease-activated receptor-1 antibody (PARI-AB) levels in patients and controls.

\begin{tabular}{|c|c|c|c|c|c|}
\hline & \multicolumn{2}{|c|}{ Patients $(\mathrm{N}=197)$} & \multicolumn{2}{|c|}{ Controls $(\mathrm{N}=200)$} & \multirow[b]{2}{*}{$p$-Value } \\
\hline & Mean (range) & Median & Mean & Median & \\
\hline PAR1-AB, U/ml & $1.508(0.1-20.6)$ & 1.1 & $4.989(0.6-36.2)$ & 4.3 & $<0.001$ \\
\hline
\end{tabular}

PAR1-AB level has lower levels in patients with EOC than in healthy controls. These results imply that unbound antibodies seem to decrease with the development of EOC, while expression of the receptor increases on the cell surface $(15,20)$ and in the blood $(30)$.

To the best of our knowledge, there has been no study that analysed PAR1-AB concentrations in the serum of patients with ovarian cancer. There is one publication by Karabulut et al. which investigated PAR1 level in serum samples of patients with EOC by ELISA in 2014. The study encompassed 44 patients and 25 controls. The serum level of PAR1 was significantly higher in the patient group $(p=0.03)$ (30). Studies that measured PAR1 expression in cancer tissue also showed an increased level compared with normal ovarian tissue $(15,20)$. Grisaru-Granovsky et al. isolated RNA from 51 paraffin blocks of invasive ovarian cancer, 11 of low invasive potential and 26 of normal ovarian tissue, and used polymerase chain reaction, in situ hybridization and immunohistochemical localization for the PAR1 protein. They showed that there was no expression of the receptor on normal ovarian tissue, while it was overexpressed in all samples of low invasive and carcinoma tissue. Furthermore, they described PAR1 as an activator of the major focal contact protein focal adhesion kinase (FAK) (15). As well as enabling integrin signalling, FAK is known to control cell spreading, survival and migration (36), which increase ovarian cancer malignancy. In another study, Wang et al. identified the MMP1-PAR1 axis as a mediator of EOC invasiveness and a potential therapeutic target.in 96 ovarian cancer tissues (20). Agarwal et al. showed that giving PAR1 pepducins intraperitoneally over 6 weeks reduced ascites and angiogenesis in mice with ovarian serous carcinoma and prolonged survival significantly (37).

In other types of cancer, the serum levels of PAR 1 vary. Tas et al. showed no effect on the receptor level in blood in patients with cutaneous melanoma (38) even though increased expression in melanoma cells has been reported (39). In gastric cancer, there was no effect on serum PAR1 level (40), while it was overexpressed in cancer tissue (41). In addition, Eturk et al. showed that the serum PAR1 level was significantly higher in a group of 80 patients with lung cancer than control group $(p<0.001)$ (42). 


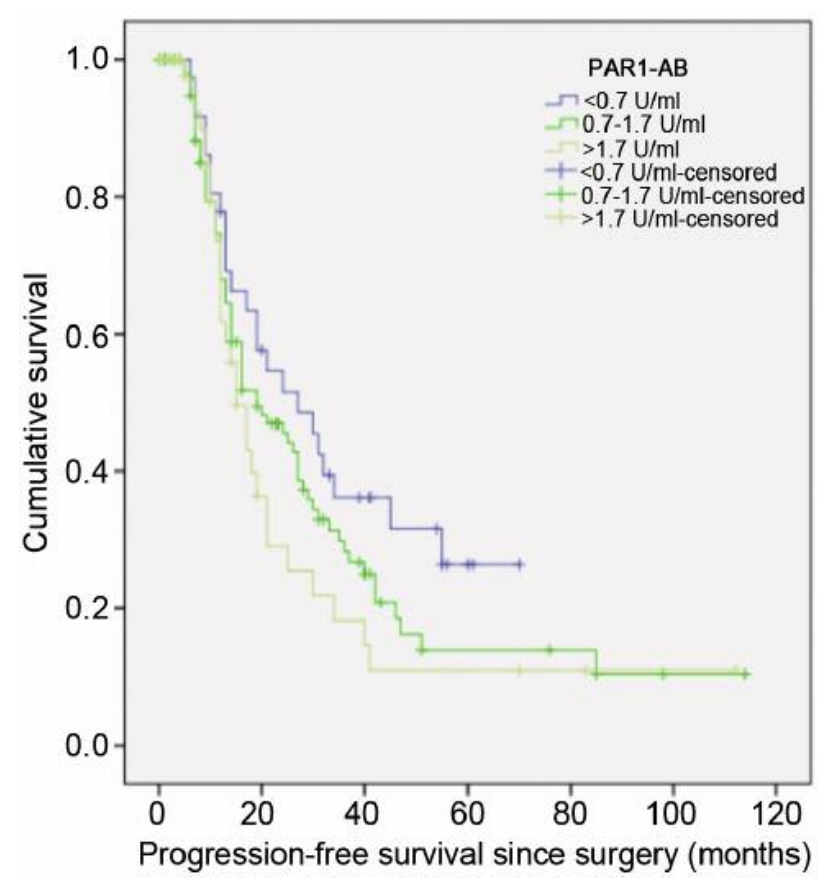

Figure 4. Progression-free survival curves for patients with epithelial ovarian cancer according to serum protease-activated receptor-1 antibody (PAR1-AB) level $(p=0.148)$.

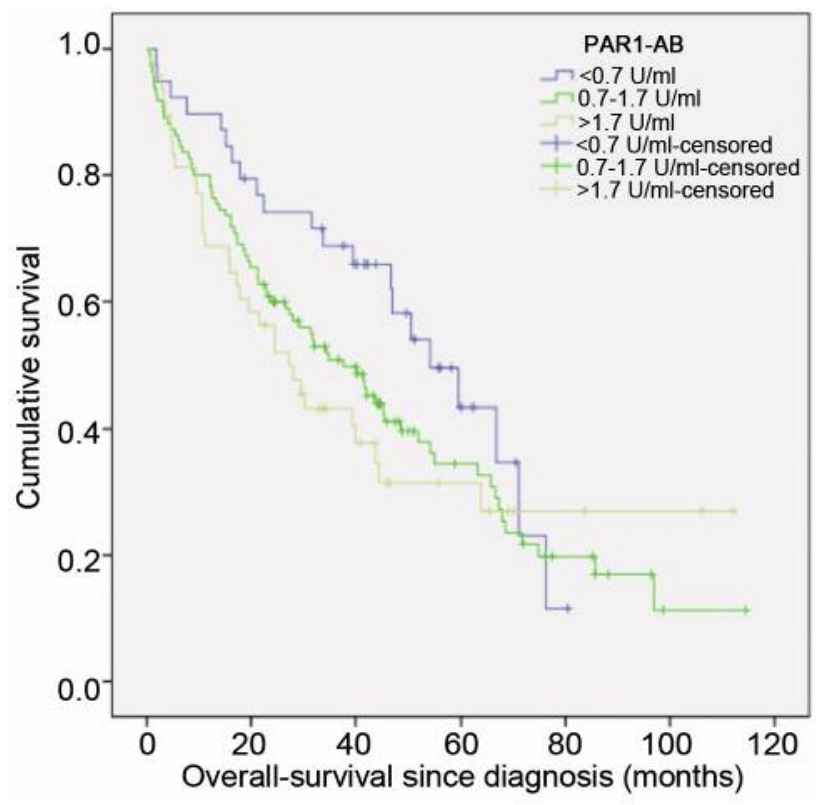

Figure 5. Overall survival curves for patients with epithelial ovarian cancer according to serum protease-activated receptor-1 antibody (PAR1-AB) level $(p=0.110)$.
Table III. Median (range) serum protease-activated receptor-1 antibody (PAR1-AB) levels according to clinicopathological parameters.

\begin{tabular}{lrll}
\hline Clinicopathological parameter & $\mathrm{N}$ & PAR1-AB, U/ml & $p$-Value \\
\hline Ascites & & & \\
$\quad$ None & 47 & $1.3(0.2-20.6)$ & $0.177^{\mathrm{a}}$ \\
$<500 \mathrm{ml}$ & 77 & $1.1(0.1-4.5)$ & \\
$>500 \mathrm{ml}$ & 73 & $0.9(0.2-4.9)$ & \\
FIGO classification & & & \\
I & 5 & $1.6(0.6-2.3)$ & $0.288^{\mathrm{a}}$ \\
II & 11 & $1.0(0.3-7.8)$ & \\
III & 135 & $1.1(0.1-20.6)$ & \\
IV & 46 & $1.45(0.2-6.3)$ & \\
Age at diagnosis & & & \\
$\quad<50$ Years & 38 & $1.1(0.4-20.6)$ & $0.464^{\mathrm{a}}$ \\
50-65 Years & 100 & $1.1(0.1-5.4)$ & \\
$>65$ Years & 59 & $1.1(0.1-4.5)$ & \\
Residual tumour mass after surgery & & & \\
$\quad$ None & 105 & $1.1(0.1-20.6)$ & $0.973^{\mathrm{b}}$ \\
Present & 92 & $1.05(0.1-6.3)$ & \\
Histological grade & & & \\
I & 8 & $2.35(0.3-20.6)$ & $0.008^{\mathrm{a}}$ \\
II & 49 & $1.0(0.1-5.3)$ & \\
III & 140 & $1.1(0.1-6.3)$ & \\
Histopathology & & & \\
$\quad$ Serous & 183 & $1.1(0.1-20.6)$ & $0.325^{\mathrm{b}}$ \\
$\quad$ Non-serous & 14 & $0.9(0.2-5.0)$ & \\
Platinum response & & & \\
Sensitive & 108 & $1.05(0.1-20.6)$ & $0.608^{\mathrm{b}}$ \\
Resistant & 50 & $1.1(0.2-4.9)$ & \\
\hline & & & \\
\hline & & & \\
& & &
\end{tabular}

Statistical analysis: ${ }^{a}$ Kruskal-Wallis test; ${ }^{b}$ Mann-Whitney $U$-test.

The decrease found here in autoantibodies against PAR1 in patients with ovarian cancer suggests any diagnostic relevance seems improbable. Nevertheless, there is evidence that targeting PAR1 might be a promising treatment strategy. Recently Zhong et al. showed that doxycycline is a direct inhibitor of PAR1-thrombin activation, with subsequent down-regulation of tumour cell migration and tumour growth (43). Furthermore Agarwal et al. showed inhibition of angiogenesis, ascites formation and metastasis in xenograft models of peritoneal EOC by giving intracellular pepducins to disturb PAR1-MMP signalling systems (37). Such findings may open a new way for future targeted chemotherapy in patients with EOC.

\section{Conclusion}

In the current study, autoantibodies directed against PAR1 were found at significantly lower levels in patients with EOC and particularly in those with histological high-grade carcinoma. There was no predictive or prognostic value in the survival analyses. Further studies with focus on the diagnostic value of the PAR1 thrombin receptor in a prospective cohort are needed. 
Table IV. Overall (OS) and progression-free (PFS) survival according to protease-activated receptor-1 antibodies (PAR1-AB) expression.

\begin{tabular}{|c|c|c|c|c|c|}
\hline \multirow[b]{2}{*}{$\begin{array}{l}\text { PAR1-AB, } \\
\mathrm{U} / \mathrm{ml}\end{array}$} & \multirow[b]{2}{*}{$\begin{array}{c}\text { Total patients, } \\
\mathrm{n}(\%)\end{array}$} & \multicolumn{2}{|c|}{ PFS } & \multicolumn{2}{|c|}{ OS } \\
\hline & & $\begin{array}{l}\text { Mean/median, } \\
\text { months }\end{array}$ & $\begin{array}{c}\text { Progression (censored), } \\
\mathrm{n}(\%)\end{array}$ & $\begin{array}{l}\text { Mean/median, } \\
\text { months }\end{array}$ & $\begin{array}{c}\text { Deaths (censored) } \\
\text { n (\%) }\end{array}$ \\
\hline$<0.7$ & 39 (19.8) & $34.6 / 27$ & $24(15)$ & $50 / 54.1$ & $21(18)$ \\
\hline $0.7-1.7$ & $110(55.8)$ & $32.8 / 19$ & $68(42)$ & $45.6 / 37.7$ & $75(35)$ \\
\hline$>1.7$ & $48(24.4)$ & $27.8 / 15$ & 29 (19) & $45.8 / 40.3$ & $32(16)$ \\
\hline Overall & $197(100)$ & $35.0 / 19$ & $121(76)$ & $47.3 / 40.3$ & $128(69)$ \\
\hline
\end{tabular}

Targeting PAR1-thrombin and MMP-1 axis is being investigated and might improve survival in patients with ovarian cancer.

\section{References}

1 Ovarian cancer, five-year stage-specific relative survival rates (2004-2008). J Natl Cancer Inst 103: 1287, 2011.

2 Rizzuto I, Stavraka C, Chatterjee J, Borley J, Hopkins TG, Gabra H, Ghaem-Maghami S, Huson L and Blagden SP: Risk of ovarian cancer relapse score: A prognostic algorithm to predict relapse following treatment for advanced ovarian cancer. Int $\mathrm{J}$ Gynecol Cancer 25: 416-422, 2015.

3 Oza AM, Cook AD, Pfisterer J, Embleton A, Ledermann JA, Pujade-Lauraine E, Kristensen G, Carey MS, Beale P, Cervantes A, Park-Simon TW, Rustin G, Joly F, Mirza MR, Plante M, Quinn M, Poveda A, Jayson GC, Stark D, Swart AM, Farrelly L, Kaplan R, Parmar MK, Perren TJ and investigators It: Standard chemotherapy with or without bevacizumab for women with newly diagnosed ovarian cancer (ICON7): overall survival results of a phase 3 randomised trial. Lancet Oncol 16: 928-936, 2015.

4 Coughlin SR: Thrombin signalling and protease-activated receptors. Nature 407: 258-264, 2000.

5 Kaufmann R, Schafberg H, Rudroff C and Nowak G: Thrombin receptor activation results in calcium signaling and protein kinase C-dependent stimulation of DNA synthesis in HEp-2g laryngeal carcinoma cells. Cancer 80: 2068-2074, 1997.

6 Rudroff C, Schafberg H, Nowak G, Weinel R, Scheele J and Kaufmann R: Characterization of functional thrombin receptors in human pancreatic tumor cells (MIA PACA-2). Pancreas 16: 189-194, 1998.

7 Kaufmann R, Junker U, Nuske K, Westermann M, Henklein P, Scheele $\mathrm{J}$ and Junker K: PAR-1- and PAR-3-type thrombin receptor expression in primary cultures of human renal cell carcinoma cells. Int J Oncol 20: 177-180, 2002.

8 Liu J, Schuff-Werner P and Steiner M: Double transfection improves small interfering RNA-induced thrombin receptor (PAR-1) gene silencing in DU 145 prostate cancer cells. FEBS letters 577: 175-180, 2004.

9 Kamath L, Meydani A, Foss F and Kuliopulos A: Signaling from protease-activated receptor-1 inhibits migration and invasion of breast cancer cells. Cancer Res 61: 5933-5940, 2001.

10 Even-Ram S, Uziely B, Cohen P, Grisaru-Granovsky S, Maoz M, Ginzburg Y, Reich R, Vlodavsky I and Bar-Shavit R: Thrombin receptor overexpression in malignant and physiological invasion processes. Nat Med 4: 909-914, 1998.
11 Nierodzik ML, Bain RM, Liu LX, Shivji M, Takeshita K and Karpatkin S: Presence of the seven transmembrane thrombin receptor on human tumour cells: effect of activation on tumour adhesion to platelets and tumor tyrosine phosphorylation. Br J Haematol 92: 452-457, 1996.

12 Heider I, Schulze B, Oswald E, Henklein P, Scheele J and Kaufmann R: PAR1-type thrombin receptor stimulates migration and matrix adhesion of human colon carcinoma cells by a PKCepsilon-dependent mechanism. Oncol Res 14: 475482, 2004.

13 Darmoul D, Gratio V, Devaud H, Lehy T and Laburthe M: Aberrant expression and activation of the thrombin receptor protease-activated receptor-1 induces cell proliferation and motility in human colon cancer cells. Am J Pathol 162: 1503$1513,2003$.

14 Jin E, Fujiwara M, Pan X, Ghazizadeh M, Arai S, Ohaki Y, Kajiwara K, Takemura T and Kawanami O: Protease-activated receptor (PAR)-1 and PAR-2 participate in the cell growth of alveolar capillary endothelium in primary lung adenocarcinomas. Cancer 97: 703-713, 2003.

15 Grisaru-Granovsky S, Salah Z, Maoz M, Pruss D, Beller U and Bar-Shavit R: Differential expression of protease activated receptor 1 (Par1) and pY397FAK in benign and malignant human ovarian tissue samples. Int J Cancer 113: 372-378, 2005.

16 Hagag AA, Nosair NA, Ghaith FM and Elshenawy EH: Prognostic value of protease activated receptor-1 in children with acute lymphoblastic leukemia. Mediterr J Hematol Infect Dis 6: e2014029, 2014.

17 Silini A, Ghilardi C, Ardinghi C, Bernasconi S, Oliva P, Carraro F, Naldini A, Bani MR and Giavazzi R: Protease-activated receptor-1 (PAR-1) promotes the motility of human melanomas and is associated to their metastatic phenotype. Clin Exp Metastasis 27: 43-53, 2010.

18 Tellez C and Bar-Eli M: Role and regulation of the thrombin receptor (PAR-1) in human melanoma. Oncogene 22: 31303137, 2003.

19 Wojtukiewicz MZ, Tang DG, Ben-Josef E, Renaud C, Walz DA and Honn KV: Solid tumor cells express functional "tethered ligand" thrombin receptor. Cancer Res 55: 698-704, 1995.

20 Wang FQ, Fisher J and Fishman DA: MMP-1-PAR1 axis mediates LPA-induced epithelial ovarian cancer (EOC) invasion. Gynecol Oncol 120: 247-255, 2011.

21 Ossovskaya VS and Bunnett NW: Protease-activated receptors: contribution to physiology and disease. Phys Rev 84: 579-621, 2004. 
22 Kuliopulos A, Covic L, Seeley SK, Sheridan PJ, Helin J and Costello CE: Plasmin desensitization of the PAR1 thrombin receptor: kinetics, sites of truncation, and implications for thrombolytic therapy. Biochemistry 38: 4572-4585, 1999.

23 Riewald M, Kravchenko VV, Petrovan RJ, O'Brien PJ, Brass LF, Ulevitch RJ and Ruf W: Gene induction by coagulation factor $\mathrm{Xa}$ is mediated by activation of protease-activated receptor 1 . Blood 97: 3109-3116, 2001.

24 Riewald M, Petrovan RJ, Donner A, Mueller BM and Ruf W: Activation of endothelial cell protease activated receptor 1 by the protein C pathway. Science 296: 1880-1882, 2002.

25 Koensgen D, Stope MB, Tuerbachova I, Bruennert D, Kohlmann T, Braicu I, Sehouli J, Denkert C, Darb-Esfahani S, Stickeler E, Sofroni D, Dahl E and Mustea A: Expression, intracellular localization, and prognostic value of plasminogen activator inhibitor 1 and PAI-1 RNA-binding protein 1 in primary and recurrent ovarian cancer: A study of the tumor bank ovarian cancer network. Gynecol Obstet Invest, 2017. doi: 10.1159/000479027. [Epub ahead of print]

26 Yousef GM, Polymeris ME, Yacoub GM, Scorilas A, Soosaipillai A, Popalis C, Fracchioli S, Katsaros D and Diamandis EP: Parallel overexpression of seven kallikrein genes in ovarian cancer. Cancer Res 63: 2223-2227, 2003.

27 Wang X, Wang E, Kavanagh JJ and Freedman RS: Ovarian cancer, the coagulation pathway, and inflammation. J Transl Med 3: 25,2005 .

28 Egan K, Crowley D, Smyth P, O'Toole S, Spillane C, Martin C, Gallagher M, Canney A, Norris L, Conlon N, McEvoy L, Ffrench B, Stordal B, Keegan H, Finn S, McEneaney V, Laios A, Ducree J, Dunne E, Smith L, Berndt M, Sheils O, Kenny D and O'Leary J: Platelet adhesion and degranulation induce prosurvival and pro-angiogenic signalling in ovarian cancer cells. PloS One 6: e26125, 2011.

29 Chalmers CJ, Balmanno K, Hadfield K, Ley R and Cook SJ: Thrombin inhibits Bim (Bcl-2-interacting mediator of cell death) expression and prevents serum-withdrawal-induced apoptosis via protease-activated receptor 1. Biochem J 375: 99 $109,2003$.

30 Karabulut S, Aksit E, Tas F, Ciftci R, Aydiner A, Yildiz I, Keskin S, Eralp Y, Yasasever CT, Vatansever S, Disci R and Saip P: Is there any diagnostic value of serum protease-activated receptor1 (PAR1) levels on determination of epithelial ovarian carcinoma? Tumour Biol 35: 4323-4329, 2014.

31 Gonda K, Miyashita M, Higuchi H, Tada H, Watanabe TM, Watanabe M, Ishida T and Ohuchi N: Predictive diagnosis of the risk of breast cancer recurrence after surgery by single-particle quantum dot imaging. Sci Rep 5: 14322, 2015.

32 Shi X, Gangadharan B, Brass LF, Ruf W and Mueller BM: Protease-activated receptors (PAR1 and PAR2) contribute to tumor cell motility and metastasis. Mol Cancer Res 2: 395-402, 2004.

33 Food and Drug Administration: FDA Guidance for Industry: Bioanalytical Method Validation. US Department of Health and Human Services, Food and Drug Administration, Center for Drug Evaluation and Research (CDER), Center for Veterinary Medicine (CVM), 2013.
34 Rustin GJ, Vergote I, Eisenhauer E, Pujade-Lauraine E, Quinn M, Thigpen T, du Bois A, Kristensen G, Jakobsen A, Sagae S, Greven K, Parmar M, Friedlander M, Cervantes A, Vermorken $\mathrm{J}$ and Gynecological Cancer Intergroup: Definitions for response and progression in ovarian cancer clinical trials incorporating RECIST 1.1 and CA 125 agreed by the Gynecological Cancer Intergroup (GCIG). Int J Gynecol Cancer 21: 419-423, 2011.

35 Chatterjee M, Mohapatra S, Ionan A, Bawa G, Ali-Fehmi R, Wang X, Nowak J, Ye B, Nahhas FA, Lu K, Witkin SS, Fishman D, Munkarah A, Morris R, Levin NK, Shirley NN, Tromp G, Abrams J, Draghici S and Tainsky MA: Diagnostic markers of ovarian cancer by high-throughput antigen cloning and detection on arrays. Cancer Res 66: 1181-1190, 2006.

36 Parsons JT, Martin KH, Slack JK, Taylor JM and Weed SA: Focal adhesion kinase: a regulator of focal adhesion dynamics and cell movement. Oncogene 19: 5606-5613, 2000.

37 Agarwal A, Covic L, Sevigny LM, Kaneider NC, Lazarides K, Azabdaftari G, Sharifi S and Kuliopulos A: Targeting a metalloprotease-PAR1 signaling system with cell-penetrating pepducins inhibits angiogenesis, ascites, and progression of ovarian cancer. Mol Cancer Ther 7: 2746-2757, 2008.

38 Tas F, Bilgin E, Karabulut S, Erturk K and Duranyildiz D: Clinical significance of serum Protease-Activated Receptor-1 (PAR-1) levels in patients with cutaneous melanoma. BBA Clin 5: 166-169, 2016.

39 Zigler M, Kamiya T, Brantley EC, Villares GJ and Bar-Eli M: PAR-1 and thrombin: the ties that bind the microenvironment to melanoma metastasis. Cancer Res 71: 6561-6566, 2011.

40 Tas F, Karabulut S, Tastekin D and Duranyildiz D: Clinical significance of serum protease-activated receptor-1 levels in gastric cancer patients. Biomed Rep 4: 489-492, 2016.

41 Fujimoto D, Hirono Y, Goi T, Katayama K and Yamaguchi A: Prognostic value of protease-activated receptor-1 (PAR-1) and matrix metalloproteinase-1 (MMP-1) in gastric cancer. Anticancer Res 28: 847-854, 2008.

42 Erturk K, Tastekin D, Bilgin E, Tas F, Disci R and Duranyildiz D: Clinical significance of serum protease activated receptor1 levels in patients with lung cancer. Eur Rev Med Pharmacol Sci 20: 243-249, 2016.

43 Zhong W, Chen S, Zhang Q, Xiao T, Qin Y, Gu J, Sun B, Liu Y, Jing $X$, Hu $X$, Zhang $P$, Zhou $H$, Sun $T$ and Yang $C$ : Doxycycline directly targets PAR1 to suppress tumor progression. Oncotarget 8: 16829-16842, 2017.
Received March 22, 2018

Revised April 20, 2018

Accepted May 2, 2018 